\title{
Fumagillin, an efficacious drug against renal sphaerosporosis of the common carp Cyprinus carpio
}

\author{
Kálmán Molnár, Ferenc Baska \& Csaba Székely \\ Veterinary Medical Research Institute of the Hungarian Academy of Sciences, PO Box 18, H-1581 Budapest, Hungary
}

\begin{abstract}
At present no reliable and efficacious drugs are available for treating fish diseases caused by myxosporeans. By feeding Fumagillin DCH salt in the diet, the authors achieved very promising results in controlling renal sphaerosporosis, one of the commonest myxosporean parasitoses of common carp Cyprinus carpio. Intraperitoneal injection of Sphaerospora renicola stages developing in the swimbladder produced sphaerosporosis only in control groups, whereas in fish consuming $0.1 \%$ fumagillin no infection developed. Farm-pond experiments also gave promising results: in fumagillintreated common carp fry a much milder sphaerosporosis developed, both in prevalence and intensity, than in control fish.
\end{abstract}

\section{INTRODUCTION}

No efficacious drugs are known against myxosporeans, parasites that frequently cause serious diseases in fish. Although Scolari (1954) and Bauer (1959) reported partial efficacy of the arsenic-containing Acetarsol (Stovarsol) against Myxosoma cerebralis, their results were not substantiated by subsequent studies (Alderman 1986). The observation of Taylor et al. (1973), that furazolidone at a dose of 152 to $194 \mathrm{mg}$ $\mathrm{kg}^{-1}$ feed was efficacious against $M$. cerebralis, has also not been confirmed. The recent study by Alderman (1986) identified 2 antiprotozoan agents of potential value against $M$. cerebralis, but the efficacy of these compounds (Proguanil hydrochloride and Clamoxyquin) still requires further testing.

While no effective drugs are available against myxosporeans, the antibiotic fumagillin has long been used successfully against different species of Microsporea. The latter are also sporozoans but are distantly related to the myxosporeans. Fumagillin was first used by Katznelson \& Jamieson (1952) for controlling nosematosis of honey bees. Kano \& Fukui (1982) were the first to report the successful use of fumagillin against the so-called 'BEKO' disease, caused by a microsporidium (Pleistophora anguillarum), of the Japanese eel Anguilla japonica.

Swimbladder inflammation, which is one of the most important diseases of the common carp, is regarded as a disease of complex aetiology. The condition is initiated by developmental stages of Sphaerospora renicola and aggravated by secondary invasion by facultatively pathogenic bacteria. Its myxosporean nature was documented by Csaba et al. (1984), who proved that the blood-parasitic C-protozoan and the K-protozoan found in the swimbladder wall correspond to early developmental stages of the kidney parasite $S$. renicola. Under laboratory conditions, Molnár (1984) and Molnár \& Kovács-Gayer (1986) succeeded in transmitting the early developmental stages of the parasite (K-protozoan) into fish reared in a parasite-free environment, and they elicited renal sphaerosporosis in a reproducible manner using the $\mathrm{K}$-protozoan stage. We used this reliable model in our medication trials against renal sphaerosporosis.

In the present paper the efficacy of fumagillin against renal sphaerosporosis is reported. Its effect on other myxosporeans was also monitored in farm-pond experiments.

\section{MATERIALS AND METHODS}

Experiments on Cyprinus carpio were performed either in the laboratory, in $40 \mathrm{l}$ aquaria, or in fish ponds. In the laboratory experiments, pathogen-free, common 
carp fry of 3 to $5 \mathrm{~g}$ body weight, hatched in an aquarium, and reared on Artemia salina nauplii and artificial feed, were used. These fish were inoculated with a homogenate prepared from the swimbladder of farmed common carp fry known to be infected with $\mathrm{K}$ protozoans. To prepare the homogenate, the infected swimbladder was squeezed through a sieve of $125 \mu \mathrm{m}$ pore size, and diluted to $2 \mathrm{ml}$ with fish physiological saline $(0.65 \%)$. An aliquot $(0.1$ to $0.2 \mathrm{ml})$ of this preparation was then injected intraperitoneally with a syringe. In the laboratory, this experiment was performed on 5 occasions. The experimentally infected fish were divided into 2 groups on each occasion. One of the groups (controls) received non-medicated feed, whereas the other received a diet containing $0.1 \%$ Fumagillin DCH (see below) from Day 1 post-inoculation (PI) up to the end of the experiment. Apart from Fumagillin DCH, the diets fed to the 2 groups were identical. In one experiment, the artifically reared fish received medicated feed for $8 \mathrm{~d}$ preceding inoculation. in this experiment, fish fed the basic diet again served as controls (Table 1).

The antibiotic fumagillin is produced by the fungus Aspergillus fumigatus and manufactured by Chinoin Pharmaceutical and Chemical Works Ltd. (Hungary) in the form of the dicyclohexylamine (DCH) salt. Its chemical name is 2,4,6,8-decatetraenedioic acid [4-(1,2-epoxy-1,5-dimethy]-4-hexenyl)-5-methoxy-1oxaspiro(2.5)oct-6-yl] monoester.

In the laboratory experiments kidneys of the sacrificed fish were examined using fresh squash preparations.

The farm-pond experiments were performed on common carp kept in 2 equal-sized ( 0.1 hectare), equally stocked fish ponds. Feed was dispensed from selffeeders in both ponds. The fish in one pond served as controls; fish in the second pond were fed the medi- cated feed containing $0.1 \%$ Fumagillin DCH. On 19 Jun 1986, after preparation of the ponds, the ponds were stocked with common carp fry that had hatched on 22 May and had been fed exclusively on plankton during the pre-rearing period in another pond. During the first few days spent in the experimental ponds, the common carp fry were also fed zooplankton, and only on 25 June was the feeding of the control and medicated feed started in the control and treated fish ponds, respectively. In the course of the fish-pond experiments, between 4 July and 6 September, attempts at demonstrating swimbladder inflammation (SBI), renal sphaerosporosis, and infections by other myxosporeans were made on 7 occasions. At every examination 11 to 20 fish were sectioned. Demonstration of the SBI agent was attempted using Giemsa-stained impression smears and histological sections stained with haematoxylin and eosin. Renal sphaerosporosis was demonstrated using fresh squash preparations of the kidney. Myxobolus cyprini was tested for by using fresh squash preparations of the muscles, whereas Thelohanellus nikolskii was detected with the unaided eye.

\section{RESULTS}

Data for the control group in Table 1 show that the transmission of K-parasites was successful and that sphaerosporosis was produced in most of the inoculated fish (in 43 of 47 fish). Only one of the 58 fish receiving $0.1 \%$ fumagillin in the feed developed sphaerosporosis, and the resulting infection was very mild. Although in the infected fish the pansporoblasts and young spores of sphaerosporosis were present as early as Day 5 PI, the kidneys were usually examined only at 10 or more d PI to ensure reliable diagnoses.

Table 1. Cyprinus carpio. Results of Fumagillin DCH treatment in common carp fry inoculated with K-protozoan stage of Sphaerospora renicola to induce renal sphaerosporosis

\begin{tabular}{|c|c|c|c|c|}
\hline $\begin{array}{l}\text { Date of intraperitoneal } \\
\text { inoculation }\end{array}$ & $\begin{array}{c}\text { Date } \\
\text { of examination }\end{array}$ & $\begin{array}{c}\text { No. of days between } \\
\text { inoculation } \\
\text { and examination }\end{array}$ & $\begin{array}{c}\text { Common carp fry fed } \\
\text { Fumagillin DCH } \\
(0.1 \% \text { in feed })\end{array}$ & $\begin{array}{l}\text { Control common } \\
\text { carp fry }\end{array}$ \\
\hline 13 Aug 1985 & 27 Aug 1985 & 14 & $0 / 5^{\circ}$ & $3 / 5$ \\
\hline 16 Aug 1985 & 9 Sept 1985 & 24 & $0 / 3$ & $3 / 3$ \\
\hline 23 Jul 1986 & 4 Aug 1986 & 11 & $0 / 12 \cdots$ & $10 / 10$ \\
\hline $23 \mathrm{Jul} \quad 1986$ & 12 Aug 1986 & 19 & $0 / 2$ & $2 / 2$ \\
\hline 13 Aug 1986 & 18 Aug 1986 & 5 & $0 / 2$ & $1 / 1$ \\
\hline 13 Aug 1986 & 25 Aug 1986 & 12 & $0 / 13$ & $5 / 5$ \\
\hline 14 Aug 1986 & 19 Aug 1986 & 5 & $1 / 2$ & $2 / 2$ \\
\hline 14 Aug 1986 & 25 Aug 1986 & 11 & $0 / 19$ & $17 / 19$ \\
\hline
\end{tabular}


Table 2. Cyprinus carpio. Course of myxosporean infections in common carp fry given medicated (0.1\% fumagillin) or nonmedicated feed in experimental farm-ponds. Figures are no. of fish infected per no. examined

\begin{tabular}{|c|c|c|c|c|}
\hline \multirow{2}{*}{$\begin{array}{c}\text { Date } \\
\text { of examination } \\
(1986)\end{array}$} & \multicolumn{4}{|c|}{ Parasite studied } \\
\hline & $\begin{array}{c}\text { Sphaerospora renicola } \\
\text { in swimbladder }\end{array}$ & $\begin{array}{c}\text { Sphaerospora renicola } \\
\text { in kidney }\end{array}$ & $\begin{array}{l}\text { Myxobolus cyprini } \\
\text { in muscles }\end{array}$ & $\begin{array}{l}\text { Thelohanellus } \\
\text { nikolskil in fins }\end{array}$ \\
\hline \multicolumn{5}{|c|}{ Fish fed medicated diet } \\
\hline 4 Jul & $1 / 13$ & $3 / 13$ & - & - \\
\hline 14 Jul & $5 / 14$ & $5 / 14$ & $5 / 14$ & $11 / 14$ \\
\hline $23 \mathrm{Jul}$ & - & $1 / 20$ & $5 / 20$ & - \\
\hline 1 Aug & - & $0 / 15$ & $7 / 15$ & - \\
\hline 13 Aug & - & $0 / 12$ & $6 / 12$ & - \\
\hline 27 Aug & - & $0 / 13$ & $6 / 13$ & - \\
\hline 6 Sep & - & $0 / 5$ & $2 / 5$ & - \\
\hline Total & $6 / 27 \mathrm{~ns}$ & $9 / 92 \cdot$ & $31 / 79^{\circ}$ & $11 / 14 \mathrm{~ns}$ \\
\hline \multicolumn{5}{|c|}{ Fish fed non-medicated (control) diet } \\
\hline $4 \mathrm{Jul}$ & $1 / 13$ & $1 / 13$ & - & - \\
\hline $14 \mathrm{Jul}$ & $10 / 12$ & $9 / 12$ & $8 / 12$ & $7 / 12$ \\
\hline $23 \mathrm{Jul}$ & - & $7 / 20$ & $8 / 20$ & - \\
\hline 1 Aug & - & $6 / 15$ & $8 / 15$ & - \\
\hline 13 Aug & - & $5 / 15$ & $8 / 15$ & - \\
\hline 27 Aug & - & $0 / 11$ & $11 / 11$ & - \\
\hline $6 \mathrm{Sep}$ & - & $0 / 5$ & $2 / 5$ & - \\
\hline Total & $11 / 25 \mathrm{~ns}$ & $28 / 91 \cdots$ & $45 / 78^{\circ}$ & $7 / 12$ ns \\
\hline
\end{tabular}

In the farm-pond experiments (Table 2) swimbladder inflammation and renal sphaerosporosis developed in both the treated and the control ponds. The acute phase of SBI (i. e. when K-protozoans are demonstrable in both stained histological preparations and impression smears) was over in $10 \mathrm{~d}$. After that only chronic forms of disease due to secondary bacterial infections were found. The only difference between the 2 stocks was in the prevalence and intensity of infection. In the control pond, on the first 2 examinations 11 of 25 fish $(44 \%)$ exhibited signs of acute SBI, whereas only 6 of the 27 fish $(22 \%)$ fed medicated feed showed these signs. Sphaerospore developmental stages and spores persisted in the lumen of the renal tubules for 5 and 3 $w \mathrm{k}$ in the control and medicated fish, respectively. During the first $5 \mathrm{wk}$ of the pond experiments (i. e. up to the 13 August sampling) 28 of 75 control fish (37\%) and 9 of 74 medicated fish ( $12 \%$ ) proved to be infected with sphaerospores. No mortality due to sphaerosporosis occurred during the experiments.

The intensity of sphaerosporosis varied in the 2 ponds during the experiment. In the untreated fish pond, infections were more severe: renal tubules were filled with, and distened by, plasmodia. In addition, spores were frequently seen and there was a larger number of infected tubular segments per microscopic field (at any given magnification) than in fish fed the fumagillin-containing feed. In the treated fish, fewer renal tubules were affected by the parasites, and infec- tion was characterized by the presence of some plasmodia and a few spores.

Table 2 summarizes the results; it shows that renal sphaerosporosis disappeared earlier in the summer in medicated fish than in control fish and that medication significantly reduced the numbers of fish affected.

The effect of medication on 2 other myxosporean infections occurring in the ponds was also monitored. Based upon the fish specimens examined by us, fumagillin medication failed to influence either the infection caused by the muscle parasite Myxobolus cyprini or that produced by Thelohanellus nikolskii, a parasite developing in the fin cartilage.

The mean body mass of fish fed the diet containing Fumagillin DCH $(40 \mathrm{~g})$ was similar to that of the control fish $(36 \mathrm{~g})$.

\section{DISCUSSION}

Our results indicate that fumagillin is a highly effective drug against Sphaerospora renicola. In the aquarium experiments, when it was given in the feed continuously at a dose of $0.1 \%$ in the feed, fumagillin prevented the development of the parasite in the renal tubules. The method described by Molnár \& KovácsGayer (1986) was highly efficient in establishing experimental $S$. renicola infections and fish infected by this method proved suitable for evaluating the effect of 
the drug. Only one of the 58 fish consuming the medicated feed developed an infection (a mild infection), while $91 \%$ of the controls became infected. Naturally, the aquarium experiments provided data only on the influence of treatment on the final sporogenic stages of sphaerosporosis. The experimental conditions necessary to test the possible efficacy of fumagillin against early developmental stages were not available.

The farm-pond experiment also proved that fumagillin is efficacious against the late, renal sporogonic stage of spaerosporosis. At the same time it suggested that fumagillin was not effective against the early stages (K-protozoans) of Sphaerospora renicola or against infections caused by Myxobolus cyprini and Thelohanellus nikolskii. The pond experiments do not allow us to decide whether this lack of efficacy was a genuine property of the drug or whether it was due to inadequate ingestion and uptake of the drug during the early stages of infection. Common carp farm-ponds are less suitable for performing experiments on the efficacy of orally administered drugs because their management technology is based on natural feeding. For example, in our case feeding of the medicated diet became possible only in the fifth week after hatching. By this time infections with early developmental stages of S. renicola, M. cyprini, and $T$. nikolskii had already been established in the fish.

To assess the efficacy of fumagillin in ponds, conditions resembling those of the aquarium experiments would be needed. Such conditions are available only in intensive fish farms where fish rearing is based exclusively on fed diets. Conditions in eel, trout, and salmon cultures could provide better opportunities for evaluating the effectiveness of the drug against myxosporean parasites. Since the drug is recommended for use only against diseases affecting fry, fumagillin treatment should not affect the meat quality of fish marketed at 2 or 3 yr of age.

Acknowledgements. The authors are indebted to András Ruttkay, Senior Researcher at the Fisheries Research Institute of Szarvas, for making it possible to carry out the farm-pond experiments

\section{LITERATURE CITED}

Alderman, D. J. (1986). Whirling disease chemotherapy. Bull. Eur. Ass. Fish Pathol. 6: 38-40

Bauer, O. N. (1959). The ecology of parasites of freshwater fishes. Izv. Gosud. Nauchno-issled. Inst. ozern. rechn. rýb. Khoz. 49: 3-215

Csaba, G., Kovács-Gayer, E., Békési, L., Bucsek, M., Szàkolczai, J., Molnár, K. (1984). Studies into the possible protozoan aetiology of swimbladder inflammation in the carp fry. J. Fish. Dis. 7: 39-56

Kano, T., Fukui, H. (1982). Studies on Pleistophora infection in eel, Anguilla japonica - I. Experimental induction of $\mathrm{mi}$ crosporidiosis and fumagillin efficacy. Fish Path. 16: 193-200

Katznelson, H., Jamieson, C. A. (1952), Control of Nosema disease of honey bees with fumagillin, Science 115: 70-71

Molnár, K. (1984). Experimental evidence that protozoans causing swimbladder inflammation in common carp (Cyprinus carpio L.) are stages of Sphaerospora renicola. Bull. Eur. Ass. Fish Pathol. 4: 14-15

Molnár, K., Kovács-Gayer, E. (1986). Experimental induction of Sphaerospora renicola (Myxosporea) infection in common carp (Cyprinus carpio) by transmission of SB-protozoans. J. appl. Ichthyol. 2: 86-94

Scolari, C. (1954). Sull impiego dello Stovarsole nella profilassi del 'compostomo' o 'lentosporiasi' della trote d'allevamento. Clin. Veterin. 77. 50-53

Taylor, E. N., Coh., S. J., Junek, B. R. (1973). Attempts to control whirling disease by continuous drug feeding. J. Wildl. Dis. 9: 302-305 